\title{
EDUCATION CHARACTER IN VIEW OF AL-GHAZALI AND ITS RELEVANCE WITH THE EDUCATION CHARACTER IN INDONESIA
}

\author{
Atik Wartini \\ Sunan Kalijaga State Islamic University of Yogyakarta, Indonesia \\ E-mail: hadiari701@yahoo.com
}

\begin{abstract}
This research is based on research library, the background of this research concerns with the deterioration of morals or character education in children and adolescents. Foreign cultures that are not properly filtered is the result of deterioration of education and children's akhlak. Imam al-Ghazali, one of the leaders of Islamic thinker that has miraculous works, one of the famous works is the book of al-walad ayyuha, described the mechanism in the moral education of children and adolescents. Education behavior is defined by al-Ghazali in this book are relevant with the character education for children and adolescents.
\end{abstract}

Keywords: Character, Ayyuha al-Walad, Morals

\section{A. Introduction}

The theme of Islamic education in the history of Islamic culture has indeed covers a lot of studies, whether it has historic cost, thought and philosophy of education, hardly touched at all. It is difficult finding Islamic studies and books that became an Islamic education as reference materials that have been said by Ahmad Syalabi in his book History of Education in 1954. The lack of literature on Islamic education motivated the author to discuss the concept of character education in view of al- Ghazali, about the moral education of children. Al-Ghazali as a thinker and an expert in Islamic law, Usul Fiqh, Fiqh, spiritual 
philosophy, Sufism and Islam. So, examine the thought of al-Ghazali in the field of character education for children becomes very possible.

The prominent of al-Ghazali was wide dimension, the book entitled "Ihya Ulum al-Din" is a proof of the quality of knowledge that he has. Not only that form of thinking but also the horrendous form of controversial comments in the book such as al-Falasifah Tahafu that hostile the rationality. The effort of al-Ghazali that protect Islam from indefinite rationality thought make him get the title "hujjatul al-Islam".

The detailed of the "Ihya Ulum al-Din" give the deep inspiration as a reference for this paper, although the writer tried to take a word of "ayyuha al-Walad" that writen by Imam al-Ghazali, the book became the standard works recitals in the system of pesantren, if students have not recited this book then they will be obliged to follow the teachings of this book.

As in the early discourse in Ihya Ulum al-Din's book, AlGhazali can combine insight and transcendental, psychological and coaching as a character in children's education foundation. Integration of science and good deed as child educational materials, and others. Psychiatric aspects become one of the most highlight by al-Ghazali. And it has completely untouched by other figures such as Ibn Miskawayh, and al-Kindi.

\section{B. Biography of Imam al-Ghazali}

Al-Ghazali's full name is Abu Hamid Muhammad Ibnu Muhammad Ibnu Muhammad al-tusi al-ghazali. He got the title Imam Abu Hamid al-Ghazali Hujjatul Islam. He was born in Tus city, a city in Kharasan, Persia in 450/1054 M, he was Persian and the descent of Banu Saljuk, the king who ruled Khurasan, Jibal, Iraq, the Arabian Peninsula, Persian, and Ahwah. His father was an honest poor book weaver; live from his own effort, in addition his father often visited the house of Muslim Scholars, learned hard and kindly helps others. His father often prayed to Allah to be given a smart and knowledgeable child, but he died when his son was a kid. 
Al-Ghazali is not the only child, he had a brother named Ahmad. Their father died when they are still kids. In the end of his life, their father entrusts his two children to a friend with a message that the both of his children must be taught until the end of his wealth legacy. His father said his regret to his friend "I have a misfortune fate, because I do not have any knowledge, I want my misfortune can be redeemed by both of my son. Take care of them and use all of my property to teach them. As Al-Ghazali father's message, his friend doing what is told by his best friend. Both of brothers were taught until the end of inheritance of his father who had died. After that they asked to seek knowledge as much as possible (al-Subkhi, tt: 194). Al-Ghazali father's friend said that the best thing you can do is being a student in a Madrasah. From that way, you will get a meal for survival. Both of the children did it and it is the cause of happiness and achieves their lofty ideals (Zainudiin, 1991: 8-9).

In the, al-Ghazali studied Fiqh to Ahmad ibn Muhammad arRazikani and Tasawuf to Yusuf an-Nasaj, until about 20 years old. After that, he went to madrassas Nizhamiyyah Madrasah and he met Imam Haramain here. Abu Bakar Aceh in Zainudiin (1991: 8) briefly tells the story:

"Al-Ghazali studied of fiqh, mantiq, Ushul and others like: the philosophy of treatises Ihwanus shafa by Karanga al-Farabi Ibn Miskawayh. So that through those teachings of philosophy, AlGhazali can explore the notions of Aristoteles, and other Greek thought. Imam Shafi"s, harmalah, Jambad, al-Muhasibi's thoughts also spots on the education of al-Ghazali.

Even Al-Ghazali exchanged the ideas with several books and various branches of knowledge, so his skill is recognized. He can also counterbalance his highly respected teacher, Imam Haramain, which at that time Al-Ghazali was 28 years old. He had caused a stir to scholars and some Ulama with the outstanding qualification in that age. In Naisapur, he rekindled the skepticism that embraced by European scholars in later periods (Zainudiin, 1991: 8). Since childhood, Al- 
Ghazali is a true knowledge lover, he had a high spirit of life, and his character is criticizing knowledge to the nature of knowledge itself. Although he had to go through many obstacles and difficulties to achieve it and sometimes difficult to achieve. Al-Ghazali said "the habit of seeking knowledge with samapai on the nature of knowledge is his habit since childhood". He studied to Ahmad ibn Muhammad alRazdikani, in Tus, and to Abu Nasir al-Ismaily in Jurjan, after he returned again to Tus in his childhood (Solomon, 1986: 6-7).

When he lived in Naisapur, Al-Ghazali studied theology and several other knowledge to al-Juwani (w. 484/1085 H). At the time, AlGhazali can show his intelligence and skill thus attracting many people. Even his teacher al-Juwaini gave the nickname to al-Ghazali with the title "Bahrun mugriq" that means ' the deep sea'. After the death of his teacher, al-Ghazali continued learning by doing rihlah to Baghdad, where the ruling of Nizam al-Mulk as Saljuk. In Baghdad, al-Ghazali was busy to teach and doing objection from Batiniyya group, Ismailiyyah, philosophers's thoughts and etc., and also in that year (483 $\mathrm{H} / 1090 \mathrm{M}$ ) he became a professor at the University Nizamiyyah in Baghdad (Al-Ghanimi, 1997: 158-189). His students really love him when he teach, because when al-Ghazali his lectures are so deep and wide. When he taught, no less than 300 students are actively listening and asking questions. Even some Ulama and public follow his developments and thoughts, so do not be surprised whether heis famous in a relatively short time (Fuel, 197). In fact, scientifically al-Ghazali had mastered many fields of knowledge. The depth of knowledge which is owned by al-Ghazali making the flaming of thought in himself. So that he himself doubted whether to approach God with his minds.

Hanafi (1976: 197) states:

"And during that time he was hit by doubts about the usage of his work, so finally he suffered a disease that cannot be treated with lahiriyyah medication, he left the job in $488 \mathrm{H}$, and went to Damascus and in the capital city he muses, reads something and writes for approximately two years, with Tasawuf as a way of life. 
Furthermore, Damascus became the goal and then headed to Palestine. He read and mused in the mosque Baitul Maqdis, and at that time also moved in his heart to perform the Hajj, and then he went to his hometown, after devoted himself to knowledge for decades and after obtaining the essential truths at the end of his life. He died in Tus in 14 Jumadil End 505 H / December 19th, 1111 M, in front his younger brother, Abu Ahmad Mujiddudin. Al-Ghazali left three daughters while his sons named Hamid had died since a little before the death of AlGhazali, because of this child he was called "Abu Hamid" (Hanafi, 1976: 198). Al-Ghazali's intellectual journey can be differentiated into several phases, first, that the deepening of the knowledge of al-Ghazali in the fields of Islamic knowledge, ranging from Fiqh, Usul Fiqh, Hadith, Tafsir al-Ulum, Kalam, even he studied directly to Imam alkalam Juwaini, one of the Kalam experts at that time.

The works produced by al-Ghazali are al-munqid min al-Dalal,: Ar-risalah al-Qudsyiah, Ihya Ulum al-din, al-durrah al-Farikhah fi kasyf ulum al-Akhirah, Al-Madnun Bih Ala Ghay Ahlih, Fasl alTafriqah, Mizan al-Amal, Iljam al-Awam an Ilm al-Kalam, Misyqat alAnwar, Al-mankhul fi Ilm al-Ushul, Maqashid al-Falasifah, Mi'yar alIlm, Al-risalahal-Ladunniyyah, Tahafut Falasifah. All of his works that ascribe to him, not all experts agree on the originality. W Montgomery Watt, for example, made a long record of "artificiality" the works of AlGhazali. Hijab part of Misyqat did not come from al-Ghazali except for the other parts. In line with Watt, Mizan also assessed that some of its contents is not genuine. Watt also rejects the entire part of the Al-risalah al-Laduniyyah. Watt is convinced that the views of al-Ghazali actually had enough by only Tahafut, Ihya, and al-Munqiz (Bakar, 165-166).

Intellectual and spiritual development of Al-Ghazali was started when studying to his teacher al-Juwaini, the material is about fiqh and kalam. In the process of learning with al-Juwaini, al-Ghazali has started to write a book entitled al-Mankhul fi Ilm al-Usuln. In this book, alGhazali discusses many things related to the theory of legal methodology. And with the qualification, al-Juwaini was interested in choosing al-Ghazali as his assistant, and became a lecturer at Nisabur

TA'DIB, 20 (2), 2015, 293-310 
until the teacher had died. From al-Juwaini, al-Ghazali knew philosophy and logic, and by studied philosophy as the foundation of kalam. Syllogistic argument was entirely accepted by al-Ghazali, who later became the foundation for thinking of Mutakalimin kalam, on the basis of that Ibn Khaldun described the al-Ghazali as a pioneer in putting the study of modern theology at the time.

In another studies, al-Ghazali (1958: 84-85) also often criticize and very careful in making decisions, and not haphazard. Al-Ghazali's objections in philosophy to the philosophers, is about the concept of their metaphysics. One of his works "Tahafut al-Falasifah" prove about this. In this book, he describes metaphysics. The discussion in this book aims to show the internal contradictions in the thinking of philosophers from a religious standpoint. Al-Ghazali did a pretty harsh criticism, but he was very careful in digesting their thinking and view. He just accused the philosophers just had done heresy. Only some of the views that he criticized. The profound critique is actually related to conservation of nature, and God does not know the particular things. Criticism of al-Ghazali is successful from three aspects. First, he managed to understand in depth the whole philosophy, at least the things that are closely related to the theology things. Second, thanks to that deep of knowledge, al-Ghazali successfully criticize effectively (Rahman, 1997: 126). Third, al-Ghazali succeeded in integrating some of the techniques of philosophy into theology. For example, the use of the syllogism in his work "al-I'tisahab fi al-I'tiqad". Using the techniques in philosophical into theology proves that his ability in philosophy, it shows the openness of the truth of philosophy.

The capability in the philosophy made al-Ghazali can explore and try to relate to other knowledge in the western, and did not criticize to abuse, but as the basic of knowledge. Instead he acknowledged that philosophy cannot bring him to fill his curiousity will of religious and eventually he built tasuwuf to achieve what he had been looking for. 


\section{Description Ayyuha Al-Walad Book and Character Education In Ayyuha Al-Walad Book}

One of famous work from al-Ghazali that was recognized by education experts who specifically concern with character education is titled "Ayyuha al-Walad". The book is written by Muhammad ibn Muhammad al-Ghazali were published by publishers Annayan in Kediri, East Java, and translated by Dr Abdul Ghani Abud, which was published in Jakarta in 2003 title "Wahai Ananda, Wasiat al-ghazali atas Pengasuhan seorang Murid kesayanganya".

Systematically, there are some chapters in the book of Ayyuha al-Walad. First, Sababa tulif Arrisalah, second, Address I'rodhullahu Anil Ibad, third, Annasihatu sah Lata Walmaskuli kubulaha, forth, AlSiti'adai Lirahmatillahi Bil Amal, fifth, Hikayah rijalul Abdillahi Sab'anini Salah, sixth, Thalaqul al-Jannha Bila Amali Dzambi Mina Dzanuubi, seventh, Al-Amal Bula Amali Januum, Al-himmatu firuh. La Taksarul Yauma Bilalail, Stalasatu Ashautu Yahbahalloh. Man Wushoya Liqomaan, Holashotul Ilmi, Alassalak Arba'ata Linur, alFuadi Tsamaniyyatalati khishola Alaha Khatamul Ashom. Khajatasallak Listakho Mursyid, Intastiro Ijaba fi Kulli Munzil.Naskhikhatul Ghazali Bitsamaniyyati Asyiya'a, Alahtaro, Du'a al-Ghazali Adhiiim.

In those books, al-Ghazali did with moral education phenomenological with emphasizing the worship first. Al-Ghazali gave an advise to his students, which is based on the Prophet:

Meaning: The sign's of Allah ta'ala turns from a servant is the servant is preoccupied with something that is of no benefit to him, people who lost their period not to worship, then they will certainly experience a prolonged regret, whoever have been aged 40 years, where the kindness cannot cover the bad side, then be ready to go to hell.

In the meaning of the nasiah, it is very broad dimension for those who has enough knowledge should implement that advice, for those who tangled with his own desires, they will be difficult to run this advice, because this advice is very beautiful and good (al-Ghazali, 2005: 
14-15). Al-Ghazali stressed that worship actually has three principles, first, keep what is commanded by Allah, second, Rida with Qadha and Qadar of Allah and accept the giving of God had given him and, third, maintain and leave the pleasure passion in seeking the pleasure of Allah.

Whereas in the case of another example is the knowledge. The importance of knowledge became the principal study in Ayyuha alWalad. In the book, al-Ghazali gave the overview of the importance of studying theology, khilaf science, medical science, a collection of poems, nujum science, arudl science, nahwu science, neuroscience, and any science that does not waste the age to achieve a high degree of Allah. Al-Ghazali said that because he had the principle "science without charity is insane, while charity without science will not succeed" (al-Ghazali, 2005: 27).

Al-Ghazali in Labib (2003: 12) having a notion about the importance of a science, to be developed considering the enormous benefits for humans, but if humans are also stingy on the knowledge they had, then in fact they fool themselves. And also the knowledge will lose when experts deceased so the science carried destroyed. The explanation above shows the importance of not hide sciences, and try to apply the science, with applying the science, then science will bring a positive influence on the lives of people who give science and if it continues to be applied by other people then that science will be useful for people other.

Al-Ghazali was sorting the science that needs to be learned, in al-Ghazali's view, science needs to be learned is the science that can be useful World and Hereafter, ranging from khilaf science (in this branch a lot of talk about the discussion and talking), medicine, diwan, astronomy, in nature astronomy are architectural, engineering buildings, etc, as well as modern science) so it is not right that al-Ghazali only emphasizes the science of Religion (Labib, 2003: 12). Keeping the science instead of being your enemy is the advice from al-Ghazali later that he wrote in the book Ayyuha al-Walad. The advice that he gave, is to keep science from becoming the enemy for ourselves. In the case, alGhazali described by asking to left four cases and perform four cases. 
The four cases must be left, first, do not argue a problem with anyone according to your means, because its sin is bigger than the benefits. So is the debate that trigger reprehensible moral, such as riya', hasud, envy, wounded heart, hostility, arrogant and others.

But if the debate aims to solve the problem and the better solution so it is not in vain then it is permitted. According to al-Ghazali (1980: 54-47), fools are those whose hearts are infected with the disease. When the heart is sick then it should be treated and repaired, rebuilt the heart with treating the soul, while fixing the soul can be filled with the concept Muhasabah al-nafs (self-correction) before bed every night, and in some matters, and it is also advocated taubikh al-Nafs (lampoon themselves). According to al-Ghazali, mind is the perfection for human, in al-Ghazali's concept about morals mind have to be guided by al-dzauq (feeling).

One of concern in character education according to al-Ghazali is becoming interpreter advice and reminder. Al-Ghazali stated that you must apply what you advise. Referring to a popular story in the time of Isa Prophet : O Ibn Maryam, Advise yourself before you advise others, if you've run it (what you advise), then you may advise others, if not, be ashame to Allah (al-Ghazali, 2005: 66-67).

Being interpreter advice should also be based on the good characteristics, first, leaving the words that are not good, or the languages that made-up, which also use poem or nazaham who crossed the line that shows the arrogance and negligence (al -Ghazali, 2005: 67). In reminding, it should contain useful things, the benefits must be strongly emphasized in giving the advice, advice is important to extend da'wah to others. The advice and order are also included in the character education that was discussed by al-Ghazali. In the advice and order will surely introduce us about the restrictions and obligations, and supported by discipline and consistency. The ban is being educational tool to prevent children from something bad, despicable, useless and prohibited by religion, so prohibition is the opposite of the order that must not do anything harmful. 
Discipline and consistency are the efforts to make a habbit which are conducted as if imposed, but it is actually the guidance and direction toward-direction works better, appropriate and courteous. Willingness to determine the good rule is a form of good discipline, not being obedient as a result of pressure from outside. In this case, instilling discipline to children necessary needs firmness about things to do and not to do or prohibited, from the beginning of irregular behavior will be achieved at the level of reasonable and good behavior (Zainudin, 1991: 83-84).

One of the emphasized things by al-Ghazali (2005: 37) in the book of al-Walad ayyuha is to adjust your words with your deeds. The detailed advice of Ghazali is "O my son, adjust your words and deeds with a view of Syari'ah, because if your science and deed incompatible with Syari' ah, indeed it will lead to error.

One of training to match words with deeds is with ryadhah. Riyadhah is an attempt to hold back and do the mental behavior. The use of mental behavior is to give morality lessons to the passion and soul of a person; usually it can be done with fasting, berkhalwat and worship diligently. Because those are the paths that was described by alGhazali in his book to get closer to God. Al-Ghazali did not devise a definitive method in any of his works included in al-Walad Ayyuha. In teaching morals to children, it should be constituted with a noble attitude, so the education which will be presented to the child will be conveyed to the maximum extent. Therefore, educating is the task requires two people with close relationship to each other such as between teachers and students or parents with their children. Al-Ghazali has fully explained it in his book. One of the teaching methods that were explained by Al-Ghazali is teaching gradually. He recommended to the teachers to teach or give the lessons done in a gradual manner, such as think the student's capability and the willingness to accept the lessons to reach the level by level and in raising the next level with the next explanation.

There are two methods here, first, is modeling. Modeling is parts of the discussion about role models in children's education. The main 
task of parents is actually to guard it, because in fact the child's instinct was created to receive the kindness and can receive the crime. The Prophet said that every child is born with a state of purity, their parents whose make them Jewish, Christian, or Majusi (Labib, 2003: 134).

The second method is habituation. The practice should be given to children as early as possible, because it will have a positive influence in a child's development further. Al-Ghazali wants this exercise is to be habituation, discipline and examples by this way. This exercise is accompanied by educational tools such as advice, orders, prohibitions, and others.

\section{The Objective of Moral Education in Children}

Educational purposes means to be achieved by education, in other words, what kind of human that you want to be with the education. Relate to the thought of al-Ghazali, he emphatically said there are two goals of moral education, even though there is only one main shape, but there is a double-edged sword there. That is human perfection which aims to get closer in qualitative sense meaning, to Allah SWT and human perfection which aims to the happiness of hereafter (Solomon, 1986: 9). The real purpose of character education was actually studying all the science, apply and become the orientation as well as the primacy of life and the happiness of Dunya and hereafter. Moral education is the soul of Islamic education that was developed by Muslims. Achieve the perfect morality is the most important goal of an education (Zainuddin, 1991: 44).

\section{E. The Relevance of Children Education in Ayyuha Al-Walad with Character Education in Indonesia}

In curriculum 2013, the education should build in character education. In this case, the concept of character education in the view of Imam Ghazali to be relevant to what is done by the Ministry of National Education. It also proves that character education was needed in building the spirit and competition of education in Indonesia. 
Al-Ghazali's moral education is based on the psychological side of the students. It shows from his view of moral concepts. For him, moral is a state or form of the soul is the source emergence of easy acts without thought and effort. In turn, it will bring moral education that develop the spirit of personality more, where education leads to the formation of after-godly man, have a good personality, sanctity of life with the element of moral wisdom, syaja'ah, iffah, and 'aadalah in him, in order to approach God. According to al-Ghazali, the purpose of moral conduct is the synonymous happiness with the main kindness and the perfection itself. Happiness, according to Al-Ghazali, is divided into two kinds: ukhrawi happiness and wordly happiness. According to him, ukhrawi happiness is the important and main happiness while wordly happiness is only a metamorphosis.

Orientation and moral education goals of al-Ghazali crystallized in the formation efforts of a perfect man towards Allah, because in fact the man is created as a servant of Allah. But the concept of moral education of al-Ghazali in fact does not forget the life of the world at all. The life of the world is the other side of the human role in the process of approach Allah. This view stands on principle because humans were also created as Allah's khalifah that is responsible for the nature's sustainable and harmonious. However, in moral education, alGhazali did not further review the sides of the moral formation of the students that relate to the relationship with the community. This means that the moral education of al-Ghazali focuses on the formation of good individual moral individually.

The relevance to the character education in Indonesia can we see in the view of modern society that grows in Indonesia now. Religion, in modern society, is faced with various problems and challenges as the direct or indirect result from the changes on a large scale (wide scale of change) which hit almost all sectors of human life. One of the challenges is the collapse of human morality. Indifference to moral values will cause the goal and the objective of development of human civilization becomes unclear. 
That is a religious responsibility to maintain and foster the awareness and human commitment to moral values, so that the negative effects of globalization can be controlled. Religion through moral education can help students to understand the essence and importance of moral values and be able to develop all its potentials to realize the moral values into real behavior. The urgency of moral education received great attention both by al-Ghazali who believe that moral education is a very important factor in human life, and morality can be transmitted to humans through education.

However, the moral education, whether in state institutions or religious institutions, is less powerful in overcoming the negative effects of globalization. Those education failures such are caused by the weakness of the methodology, the difference between good orientation of individual and social (public moral versus private moral) and epistemological foundation of moral education. In terms of methodology, moral education has more doctrinaire patterned so it do not give the opportunity and sufficient space for the students to chew moral teachings critically. In addition, the moral education is also more likely to rely on a method that is teacher centered as a consequence. Learners are the passive objects, which are always obedient, even considered as a figure that needs to be honed and shaped. This kind of models education is leading to the transfer and transmission processes. This method is initiated by al-Ghazali.

However, it does not mean that al-Ghazali's methodology is very useful. Teacher centered methods emphasized the exemplary teacher in the present context has urgent relevance and needed. The issue of the lack of role models also has contributed to the failure of moral education over the years. Therefore, moral education must develop an exemplary aspect is not just a call, commands moreover forcefulness. Moral education should also take place in a dialogical, critical not dogmatic or doctrinaire.

Second, the weakness of moral education today is the lack of integration of the overall orientation of moral education. Fragmentation orientation of moral education is the evident from the opinion of al- 
Ghazali. The orientation of moral education of al Ghazali only emphasize the formation of individual good with the advent of the sanctity of life to draw closer to Allah, but it is separate from the social reality. The orientation of al-Ghazali's moral education that emphasizes individual piety has relevancy like today's modern future where humans experiencing a crisis of identity, meaning emptiness of life and desperately need guidance in Him. On the other hand, individual piety was formed individuals who are less concerned with social reality.

As we know, today is the glorification of individualism left a serious problem in society, although it must be recognized that individualism open up freedom for man so that creativity and innovation can be grow flourish, but keep in mind. at the same time individualism carry the seeds of bitterness. First, a human with the individualistic attitude tends to demand freedom without limits or wholly consequently neglected the normative regulations. Second, human is less concerned about the social importance because the stir of his own interests. Louis Leahy even mentions that the modern thought ideology considers a man is responsible only to himself. That kind of symptoms are further entrenched as the explotion of modernization wave. Modernization which was originally seen as bearers of progress and human development brings harmful effects that follow. The worst result is a shrinking of the culture that took place in people's lives in various fields and places. Thus, almost half of people lose the meaning and orientation on life.

In this amid of reality, a long tradition aside and considered obsolete, while new values do not give any goodness. This turn led to the destruction of the social order, so that the cohesive unity is faded along with deprived individual human values in life together. The identity of the individual becomes abstract and based only on his own free choice. The awareness of a person is a citizen of the community and does well for the community, as a whole is good for them is slowly disappearing even tend to disappear (Pole 1993: xiv-xv). Individualism puts the individual above the collectivity by it self, otherwise norms do not have the strong enough authority to establish the self-awareness. At

TA'DIB, 20 (2), 2015, 293-310 
this exact point, the man returned to lose the guiding principle in determining the direction of life. Third, relates to the epistemological ground. Moral education with the transfer of the dogmas as a moral authority that is highly marginalized minds in chewing and internalize the rules and moral order and replace it with the guidance of strict sheikh as proposed by al-Ghazali, would marginalize the critical function of the human mind in realize the reality. It is very naive if in this modern era as now, marginalized the role of the human mind. The anxiety of young people of modern era in looking for a new spirituality lest caused by a narrowing of the space for ventilation minds to formulate their religious ethics in accordance with the challenges faced. Cultural barriers, boundaries, the more transparent so that the mind may be not unaffected by the wave of culture and science. This is not relevant to the spirit of rationalism that is promoted by modern society.

From the explanation above, the foundation of moral education should provide a balanced portion of the human mind in interpreting the values that are contained in religion. Not like Durkheim that is more favor in ratio and reject religion resulting the loss of transcendent values in life, or al-Ghazali who emphasized the role of wahyu totally by marginalizing ratio. So that religious ethics becomes stiff, rigid and puritanical. But there must be a balance in both.

Therefore it should be placed above moral education when the elements of religion are fundamental values that comprehensively understood from a review of various perspectives, including historical study that becomes the reflects of the present socio-cultural. With full consideration of the value, moral education will always be open to criticism for the continued transformation.

All of the value components are systemically rooted in religion and better reflect the inclusive and universal character is the system of cultural values, social values system, the psychological value system, the value system of human behavior that includes interrelation and intercommunication with each other (Arifin, 1996: 140- 141). Thus, moral education should be contained in the values of humanitarianismtranscendental that can be relied upon civil ethics that is able to arouse 
awareness of the existence of human intrinsic moral responsibility in the discharge of their mandate each as a servant of the Khalik. And the transcendent aspect which is an existential element that exists in every human being as a human being who is always trying to get past the limits of humanity or what is called self-transcendence towards kasalehan ritual and social piety.

Moral education should also have an ethical vision to people's lives, try to anticipate the impact of social change as a result of the industrial revolution and the spread of capitalism resulted the gap between the public and private so that eclipsed the public responsibility of the citizens because of the strong encouragement of satisfying personal interests. So that moral education could produce moral sentiments and mutual love people. Ethical vision of morality implies that every society has a wisdom of natural morality born of the equations of human rights and the equation in fulfilling moral obligations, from which individuals and communities agree creates a social contract in legitimizing social formations that exist ensure cohesion social. Finally, in spite of all the advantages and disadvantages of moral education proposed by Al-Ghazali, at least provide new insights, innovative ideas and contributions of modern society. Not to stop the pace of globalization in modern society, but to raise awareness and human commitment to moral values, so that the negative effects of globalization can be controlled.

\section{F. Conclusion}

The thoughts offered by the education offered by Imam al-Ghazali so grounded, especially if we exactly examine the book that became the standard's schools for new students, the book of ayyuha al-Walad, in this book with the easy language. Between teachers and student, alGhazali wants to embed three principles, first, religion as a foundation for character education, because in religion there is the Prophet, the Prophet Muhammad that had been explained in the A Qur'an as a highly spirited akhlaqul al-Karimah. Second, the value of tradition also becomes good moral foundation, in this case according to al-Ghazali the 
tradition that are still relevant to Islamic norms. Third, reconditional in understanding morality, within the limits of this reconditional also does not eliminate the core values of character education in Islam. 


\section{References}

Al-Ghanimi, Abu al-Wafa al-taftazani. (1997). Sufi dari Zaman ke Zaman. terjemahan, Ahmad Rifa'i. Bandung: Pustaka Pelajar.

Hanafi, A. (1976). Filsafat Islam. Bandung: Bulan Bintang.

Hamid, Al-Ghazali. (1958). Tahafut al-Falasifah. Sulaiman Dunya. Kairo: Dar al-Ma'arif. . (1980). Ihya Ulumuddin. Beirut: Dar al-Fikr. . (2005). Ayyuha Walad. Bandung: Irysad Baituss

Slam. . (2003). Ringkasan Ihya Ulumuddin. terjemahan Labib MZ. Surabaya: Bintang Usaha Jaya.

Rahman, Fazlur. (1997). Islam. terj. Mahyudin. Jakarta: Pustaka.

Sulaiman, Fahtiyyah al-Hasan. (1986). Konsep Pendidikan al-ghazali, terj Ahmad Hakim dan M. Imam Aziz. Jakarta: Perhimpunan Pengembangan Pesantren dan Masyarakat (P3M).

Tajuddin Abi Nassar al-Wahab ibn Ali al-Kahfai al-Subkhi. (tt). Tabaqat al-Syafi'iyyah al-Kubro. Kairo: Isa al-Babi al-Halabi.

Zainudiin. (1991). Seluk Beluk Pendidikan Imam al-Ghazali. Jakarta: Bumi Aksara. 